\title{
АНАЛІЗ ПРІОРИТЕТНОСТІ ПАРАМЕТРІВ ДЛЯ ОЦІНКИ ПЕРСПЕКТИВНОСТІ ВИКОРИСТАННЯ ГЕОТЕРМАЛЬНИХ ОБ'ЄКТІВ
}

\author{
А.А. Барило \\ Інститут відновлюваної енергетики НАН України, \\ 02094, вул. Гната Хоткевича 20А, м. Київ, Україна.
}

У статті методом експертного оцінювання виконано аналіз пріоритетності параметрів геотермальних об'єктів для визначення можливості і перспективності їх використання з метою енергопостачання. Під геотермальним об'єктом розуміється умовна свердловина, на базі якої можливе створення системи геотермального енергопостачання з урахуванням наявності потениійного споживача. Для експертного оцінювання була розроблена опитувальна анкета і обрана репрезентативна група експертів в кількості 12 чоловік. Середній коефічієнт компетентності експертів склав 8 балів за десятибальною шкалою. Розглянуто параметри двох категорій: перші пов'язані з наявністю геотермального ресурсу, другі - 3 умовами транспортування і особливостями потенційних споживачів енергії. Всього в опитуванні аналізувалося 30 параметрів. Для кожного параметра встановлювалися вагові коефіцієнти. Результати опитування були оброблені шляхом знаходження середньої арифметичної, середньо зваженої і медіани оцінки. Ступінь узгодженості думок експертів по кожному параметру визначався методом знаходження коефіцієнта варіації, а для всього експертного оцінювання коефіиієнта конкордації Кенделла. Розрахунки показали, щзо узгодженість оцінок експертів достатня для прийняття рішення про перелік пріоритетних параметрів і їх вагових коефіцієнтів. Отримані результати можуть бути використані при створенні електронних баз даних геотермальних об'єктів і під час розробиі методики вибору перспективних свердловин для першочергового освоєння геотермальних ресурсів. Бібл. 10, табл. 4, рис. 5.

Ключові слова: геотермальний об'єкт; експертне очінювання; параметр; ваговий коефіиієнт.

\section{PARAMETER PRIORITY ANALYSIS TO EVALUATE THE PROSPECT OF GEOTHERMAL OBJECTS UTILIZATION}

\author{
A. Barylo \\ Institute of Renewable Energy of the National Academy of Sciences of Ukraine, \\ 02094, 20A Hnata Khotkevycha St., Kyiv, Ukraine.
}

In the article analyses of parameter priority to evaluate the prospect of the geothermal objects utilization to determine the possibility and prospects of their use for the purpose of energy supply has been executed by the method of expert estimation. The geothermal object is nominal well on the basis of which possible to establishment of the geothermal energy distribution system bearing in mind the potential consumer. For expert estimation a survey questionnaire worked out and a representative group of experts was composed in the amount of 12 people. The average expert competency coefficient was 8 points on a ten-point scale. The parameters of two categories are considered. The first parameters are related to the availability of geothermal resource, the second - to the conditions of transportation and features of potential energy consumers. In total, 30 parameters were analyzed in the survey. Weighting coefficients were set for each parameter. The survey results were processed by finding arithmetic, weighted average and median scores. The degree of experts' opinions agreement on each parameter was determined by the method of finding the coefficient of variation. For the whole expert poll in general was determined by the coefficient of Kendell's concordance. The calculations showed that the consistency of expert estimates is sufficient to decide on a list of priority parameters and their weighting factors. . The obtained results can be used in the creation of the geothermal databases and in the development of a methodology for selecting prospective wells for the primary development of geothermal resources. Ref. 10, tabl. 4, fig. 5.

Keywords: expert estimation, geothermal object, parameter, weighting factor, statistic, consistency

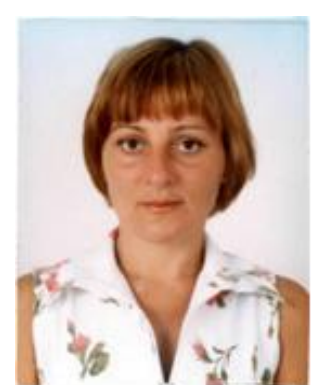

А.А. Барило

A. Barylo
Відомості про автора: науковий співробітник відділу геотермальної енергетики Інституту відновлюваної енергетики НАН України.

Освіта: Київський Державний університет, факультет гідрогеології та інженерної геології.

Наукова сфера: відновлювана енергетика, геотермальна енергетика, використання тепла довкілля.

Публікації: 58.

ORCID: 0000-0001-7981-6464

Контакти: тел./факс: +38 (044) 206-28-09

e-mail: geotherm@ukr.net
Author information: researcher at Geothermal

Energy Department, Institute of Renewable

Energy of National Academy of Sciences of Ukraine.

Education: Kyiv National University, Faculty of Hydrology and Engineering Geology.

Research area: renewable energy,

geothermal energy, use of environmental heat.

Publications: 58.

ORCID: 0000-0001-7981-6464

Contacts: phone/fax: +38 (044) 206-28-09

e-mail: geotherm@ukr.net 
Вступ. Україна характеризується сприятливими природними умовами для розвитку глибинної геотермальної енергетики, проте на даний час ця галузь нетрадиційної енергетики широкого поширення не отримала. Виняток становить використання тепла верхніх шарів землі за допомогою теплонасосних установок, яке в останні роки набуло значного підйому $[1,2]$.

Однією 3 причин такої ситуації $є$ слабка підготовленість ресурсної бази для використання геотермальних джерел енергії. Спеціальні дослідження на термальні води проведені тільки в Закарпатській області, АР Крим та частково в Херсонській області.

Переважна більшість відомостей про термальні водоносні горизонти України була отримана під час пошуку, розвідки та розробки нафтових і газових родовищ, тим самим дослідження водоносних горизонтів проводилися стосовно цих родовищ. Основна мета таких досліджень полягала у вивченні умов формування покладів вуглеводнів, взаємодії їх з водоносними горизонтами, у контролі процесу заводнення та режиму експлуатації родовищ, тощо [3].

Для отримання вихідних даних щодо проектування енергетичних установок, які використовують геотермальні ресурси, такої інформації недостатньо, оскільки вона дає лише попередні загальні відомості. Проте, ця інформація може і повинна бути використана для розвитку геотермальної енергетики, планування більш детальних стадій досліджень геотермальних родовищ, а також для вибору перспективних об'єктів першочергового освоєння геотермальних джерел енергіï.

Мета дослідження. Експлуатація геотермальної системи енергопостачання (ГСЕ) складний багатофакторний процес, при якому у взаємодії знаходяться геологічна середа, що містить теплову енергію, технічні засоби видобутку та утилізації природного теплоносія, енергогенеруюче обладнання. Також на процес функціонування таких систем істотний вплив чинять специфічні особливості споживачів.

Тому прийняття рішення про перспективність геотермального об'єкта для створення систем геотермального енергопостачання повинно грунтуватися на аналізі параметрів всіх перерахованих вище елементів.
Метою даної роботи $є$ визначення параметрів, що впливають на перспективність геотермального об'єкта, ранжування параметрів за значимістю і визначення їх вагових коефіцієнтів пріоритетності для використання у геотермальній енергетиці.

Постановка завдання. На території України існують десятки тисяч геотермальних об'єктів. Кожне геотермальне родовище унікальне за своєю природою і має своїй неповторний набір кількісних показників параметрів. У ситуації, коли відсутні достовірні статистичні дані, а вибір, обгрунтування і оцінка рішення не можуть бути виконані на основі точних розрахунків, найбільш доцільно використовувати експертні методи дослідження.

Ці методи дозволяють отримати кількісні показники при використанні на вході якісних даних, а також провести аналіз множинних факторів, які складно оцінити математично. Методи експертного оцінювання найбільш ефективні щодо проведення прогнозних досліджень, а також під час перспективного планування.

Метод «Дельфі» є одним 3 найбільш вживаних методів експертного оцінювання. Він простий у використані і дає результати, надійність яких підтверджується статистичними показниками [4].

Тому для вирішення поставленого завдання був використаний метод експертних оцінок, а саме метод «Дельфі». Суть методу полягає в отриманні від експертів необхідної інформації, подальшої її обробці і використанні для підготовки і прийняття рішень. При цьому вважається, що надана експертом інформація $\epsilon$ результатом інтуїтивно - логічного аналізу проблеми, заснованого на практичному досвіді, знаннях і компетентності експерта в досліджуваній області.

Перевагами використання даного методу $\epsilon$ анонімність і заочність процедури опитування (опитування проводиться в письмовій формі, експерти один $з$ одним не контактують), а також виконання, як що потрібно, декількох турів експертних досліджень 3 використанням результатів попереднього туру для досягнення узгодженості отриманих результатів. Етапи проведення експертної оцінки наведені на рис. 1. 


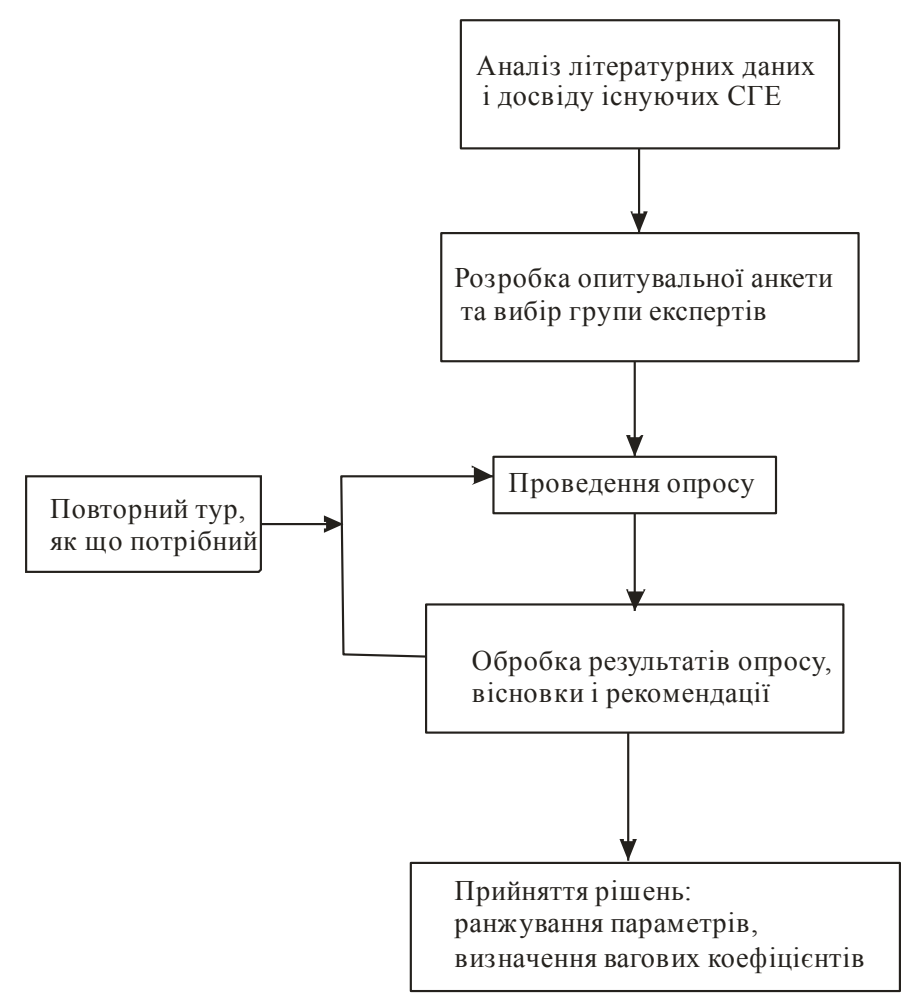

Рис. 1. Етапи проведення експертної оцінки пріоритетності параметрів методом «Дельфі».

Fig. 1. Stages of expert assessment of the parameters priority by the "Delphi" method.

Ефективність використання методу «Дельфі» безпосередньо залежить від чіткості формулювань, ретельної продуманості і якості складеної опитувальної анкети, а також від репрезентативності сформованої групи експертів [4].

Важливим питанням є кількість експертів учасників опитування. Ця кількість, з одного боку, повинна бути достатньою для прийняття обгрунтованого рішення за підсумками експертного оцінювання, з іншого боку - не бути занадто великою, щоб не затягнути, а іноді унеможливити процедуру опитування, оскільки експерти беруть участь в оцінюванні на добровільних засадах.

В роботі [5] запропонована методика визначення мінімальної кількості експертів для надійно обгрунтованого прийняття рішення. Згідно цієї методики у спрощеному вигляді мінімальну кількість експертів можливо визначити за формулою: $m=\sqrt{n}$, де $\mathrm{n}-$ кількість параметрів, які оцінюються у дослідженні; $\mathrm{m}$ мінімальна кількість експертів. Оскільки в нашому дослідженні оцінюються 30 параметрів, тому група експертів повинна складатися не менше ніж 36 чоловік.

Геотермальна енергетика знаходиться на стику наук, тому до експертних досліджень були залучені фахівці суміжних спеціальностей, а са- ме: геології, гідрогеології, геотермії, теплотехніки, енергетики та екології.

В Украйні безпосередньо проблемами глибинної геотермальної енергетики займається Інститут відновлюваної енергетики НАНУ. Крім фахівців цього інституту в експертному оцінюванні були задіяні спеціалісти Інституту технічної теплофізики НАНУ, Інституту геофізики НАНУ, Національного університету «КПІ», Київського національного університету ім. Тараса Шевченка, Комунального підприємства «Київтеплоенерго»ТЕЦ-6.

Група експертів була складена 3 дванадцяти фахівців, діяльність семи 3 яких безпосередньо пов'язана $з$ геотермальної тематикою, троє займаються проблемами енергетики і теплопостачання, двоє - гідрогеологією. Дев'ять 3 фахівців мають ступінь кандидата, а четверо - доктора технічних або геолого-мінералогічних наук.

На основі аналізу літературних даних[6-11], досвіду діючих СГЕ за участю експертів була розроблена опитувальна анкета. Зазначимо, що експерти брали активну участь в розробці анкети як на підготовчій стадії опитування, так і в процесі анкетування: вони мали можливість додавати до переліку опитування додаткові параметри або виключати неважливі параметри шляхом нульових оцінок. 
Опитувальна анкета складається 3 чотирьох частин. У першому розділі анкети наводиться інформація про цілі, предмет і способи реалізації даного дослідження.

Пояснюється, що в оцінці розглядаються параметри, які зазвичай отримують під час буріння i випробування геотермальних, газоконденсатних і нафтових свердловин, тобто початкові параметри. Цих параметрів, як правило, недостатньо для виконання точних техніко-економічних розрахунків геотермального проекту в цілому, але на підставі яких можна зробити відбір перспективних геотермальних об'єктів і рекомендувати ці об'єкти для подальшого більш детального дослідження.

У другому розділі проводиться визначення компетентності експерта за темою дослідженя шляхом його самооцінки. При цьому експертам запропоновано оцінити свою компетентність за десятибальною шкалою за такими напрямками: рівень теоретичних знань, практичний досвід та відповідність області діяльності експерта 3 предметом досліджень. Середній коефіцієнт самооцінки експертів склав 8 балів.
У третьому і четвертому розділах анкети наведено перелік параметрів, які підлягають аналізу пріоритетності для оцінки перспективності використання геотермального об'єкта. Назви параметрів наведено в табл. 1. Під геотермальним об'єктом розуміється умовна свердловина, на базі якої можливе створення СГЕ, 3 урахуванням наявності потенційного споживача геотермальної енергії.

Всі параметри були поділені на дві категорії: параметри, що пов'язані 3 геолого- гідрогеологічними і геотермічними умовами об'єкта, i параметри, пов'язані з техніко-технологічними умовами об'єкта і особливостями споживачів.

Оскільки перша категорія параметрів характеризує на сам перед наявність геотермального ресурсу свердловини, тому параметри першої категорії оцінюються за десятибальною шкалою. Параметри другої категорії є вторинними, вони характеризують умови транспортування та використання цього ресурсу, і оцінюються за п'ятибальною шкалою.

Таблиця 1. Рівень компетентності та результати 1-го туру експертного оцінювання (перша категорія параметрів).

Table 1. Level of competence and results of the first round of expert evaluation (first category of parameters).

\begin{tabular}{|c|c|c|c|c|c|c|c|c|c|c|c|c|}
\hline № експерта & $\mathbf{I}$ & II & III & IV & $\mathbf{V}$ & VI & VII & VIII & IX & $\mathbf{X}$ & $\mathbf{X I}$ & XII \\
\hline Рівень компетентності & 9 & 8 & 6 & 10 & 8 & 8 & 7 & 9 & 8 & 7 & 10 & 9 \\
\hline \multicolumn{13}{|c|}{ Параметри 1-ої категорії: } \\
\hline 1.1 Питомий дебіт свердловини & 10 & 10 & 10 & 10 & 10 & 10 & 10 & 10 & 10 & 10 & 9 & 10 \\
\hline 1.2 Статичний рівень продуктивного горизонту & 10 & 3 & 8 & 8 & 9 & 9 & 4 & 9 & 7 & 9 & 7 & 8 \\
\hline 1.3 Температура на гирлі свердловини & 10 & 10 & 10 & 9 & 10 & 10 & 10 & 10 & 10 & 10 & 8 & 10 \\
\hline 1.4 Пластова температура & 9 & 3 & 8 & 10 & 7 & 7 & 7 & 8 & 6 & 8 & 7 & 10 \\
\hline 1.5 Глибина залягання продуктивного горизонту & 10 & 2 & 9 & 8 & 8 & 9 & 8 & 9 & 8 & 8 & 8 & 7 \\
\hline 1.6 Площа розповсюдження продуктивного горизонту & 10 & 7 & 10 & 7 & 8 & 9 & 8 & 8 & 9 & 8 & 8 & 7 \\
\hline 1.7 Товщина (потужність) продуктивного горизонту & 9 & 7 & 10 & 9 & 8 & 9 & 8 & 8 & 9 & 8 & 8 & 9 \\
\hline $\begin{array}{l}1.8 \text { Коефіцієнт фільтрації (проникності) продуктивного } \\
\text { горизонту }\end{array}$ & 10 & 6 & 10 & 8 & 8 & 9 & 9 & 9 & 10 & 8 & 7 & 6 \\
\hline 1.9 Геотермічний градієнт & 9 & 3 & 6 & 8 & 2 & 4 & 6 & 4 & 8 & 6 & 6 & 4 \\
\hline 1.10 Глибинний тепловий потік & 7 & 2 & 6 & 6 & 2 & 4 & 6 & 4 & 6 & 7 & 6 & 4 \\
\hline 1.11Пористість продуктивного горизонту & 7 & 2 & 8 & 7 & 7 & 8 & 9 & 6 & 9 & 8 & 6 & 8 \\
\hline 1.12 Мінералізація підземних термальних вод & 10 & 8 & 5 & 8 & 9 & 6 & 8 & 9 & 8 & 8 & 9 & 6 \\
\hline $\begin{array}{l}1.13 \text { Вміст газу у підземних водах продуктивного гори- } \\
\text { зонту }\end{array}$ & 10 & 9 & 7 & 9 & 9 & 7 & 6 & 7 & 9 & 8 & 5 & 8 \\
\hline $\begin{array}{l}1.14 \text { Склад газової фракції підземних вод продуктивного } \\
\text { горизонту }\end{array}$ & 10 & 9 & 7 & 7 & 7 & 8 & 8 & 7 & 9 & 6 & 7 & 9 \\
\hline 1.15 Вміст механічних домішок & 10 & 4 & 4 & 6 & 7 & 4 & 8 & 6 & 7 & 7 & 5 & 10 \\
\hline 1.16 Прийомистість продуктивного горизонту & 10 & 6 & 10 & 9 & 10 & 9 & 10 & 10 & 10 & 9 & 8 & 10 \\
\hline 1.17 Здатність підземних вод до солевідкладення & 10 & 9 & 8 & 8 & 8 & 9 & 9 & 5 & 9 & 8 & 8 & 4 \\
\hline 1.18 Корозійна активність підземних вод & 10 & 8 & 8 & 7 & 8 & 8 & 9 & 5 & 9 & 8 & 6 & 4 \\
\hline
\end{tabular}


Таблиця 2. Результати 1-го туру експертної оцінки (друга категорія параметрів).

Table 2. Results of the first round of expert evaluation (second category of parameters).

\begin{tabular}{|c|c|c|c|c|c|c|c|c|c|c|c|c|}
\hline № експерта & I & II & III & IV & $\overline{\mathbf{V}}$ & $\overline{\text { VI }}$ & VII & VIII & IX & $\bar{X}$ & $\mathbf{X I}$ & XII \\
\hline 2.1 Дозвіл на розробку геотермального родовища & 5 & 4 & 5 & 5 & 5 & 5 & 5 & 5 & 5 & 5 & 5 & 5 \\
\hline 2.2 Наявність споживачів електричної енергії & 5 & 3 & 1 & 1 & 4 & 5 & 4 & 5 & 4 & 4 & 4 & 4 \\
\hline 2.3 Наявність споживачів теплової енергії & 5 & 5 & 5 & 5 & 5 & 5 & 5 & 5 & 5 & 5 & 4 & 5 \\
\hline $\begin{array}{l}2.4 \text { Категорія споживачів (житлово-комунальна, проми- } \\
\text { слова, агропромислова, сочуіальна, бальнеологія, інш.) }\end{array}$ & 4 & 1 & 4 & 3 & 4 & 4 & 3 & 3 & 3 & 4 & 4 & 3 \\
\hline 2.5 Відстань від геотермального об’єкта до споживачів & 5 & 4 & 4 & 4 & 4 & 5 & 5 & 5 & 5 & 5 & 4 & 4 \\
\hline 2.6 Потенційне навантаження споживачів & 5 & 4 & 5 & 3 & 5 & 5 & 4 & 4 & 4 & 5 & 4 & 5 \\
\hline $\begin{array}{l}2.7 \text { Наявність централізованої системи теплопостачання } \\
\text { у потенційних споживачів }\end{array}$ & 5 & 3 & 4 & 4 & 3 & 4 & 4 & 4 & 5 & 4 & 3 & 3 \\
\hline 2.8 Тип споруд (нові будови, модернізовані або старі) & 4 & 4 & 2 & 3 & 4 & 3 & 3 & 3 & 3 & 3 & 3 & 3 \\
\hline 2.9 Річний графік споживання тепла & 4 & 4 & 4 & 2 & 4 & 4 & 3 & 5 & 5 & 4 & 4 & 4 \\
\hline 2.10 Температурний графік мережевої води & 4 & 5 & 3 & 3 & 3 & 5 & 5 & 3 & 5 & 5 & 4 & 3 \\
\hline 2.11 Наявність джерела охолоджуючої води & 4 & 3 & 1 & 4 & 3 & 5 & 3 & 4 & 4 & 3 & 3 & 3 \\
\hline 2.12 Доступність до електромереж та їх потужність & 5 & 5 & 3 & 3 & 4 & 5 & 4 & 5 & 5 & 4 & 5 & 5 \\
\hline
\end{tabular}

Матеріал і результати досліджень. Перший тур експертної оцінки показав, що всі параметри, перелічені в Опитувальний анкеті, на думку фахівців, впливають на попередній відбір свердловин 3 метою геотермального енергопостачання. При цьому ступінь важливості параметрів різна. Додаткових параметрів експертами запропоновано не було, що вказує на коректність і обгрунтованість розробленої анкети.
Результати 1-го туру експертної оцінки наведені в табл. 1. і табл. 2. Далі був проведений аналіз отриманих результатів експертного опитування та обробка результатів статистичними методами. При цьому для кожного параметра були визначені за формулами, що наведені у Таблиці 3., наступні статистичні характеристики: середнє арифметична оцінка, середньозважена оцінка і медіана (рис. 2 і рис. 3 та табл. 4.).

Таблиця 3. Статистичні характеристики, що розраховувались для визначення коефіцієнтів вагомості параметрів і узгодженості результатів опитування.

Table 3. Statistical characteristics calculated to determine weighting coefficients of the parameters and the consistency of the survey results.

\begin{tabular}{|c|c|c|}
\hline $\begin{array}{c}\text { Статистична харак- } \\
\text { теристика }\end{array}$ & Формула розрахунку & Позначення \\
\hline $\begin{array}{l}\text { Середнє арифметичне } \\
\text { значення }\end{array}$ & $\bar{x}=\frac{1}{n} \cdot \sum_{i=1}^{n} x_{i}$ & $\begin{array}{l}x_{i}-i \text {-тий параметр; } \\
n-\text { кількість параметрів; }\end{array}$ \\
\hline $\begin{array}{l}\text { Середньозважене зна- } \\
\text { чення }\end{array}$ & $\bar{x}_{36}=\frac{\sum_{i=1}^{n} K_{i} \cdot x_{i}}{\sum_{i=1}^{n} K_{i}}$ & $\begin{array}{l}K_{i}-\text { рівень компетентності; } \\
i \text {-ого експерта }\end{array}$ \\
\hline $\begin{array}{l}\text { Коефіцієнт } \\
\text { варіації }\end{array}$ & $V=\frac{\sqrt{\frac{1}{n} \sum_{i=1}^{n} x_{i}-\bar{x}^{2}}}{\frac{1}{n} \sum_{i=1}^{n} x_{i}-\bar{x}}$ & ті ж самі \\
\hline $\begin{array}{l}\text { Коефіцієнт конкордації } \\
\text { Кендалла }\end{array}$ & $\begin{array}{l}W=\frac{12}{m^{2} \cdot n^{3}-n} \cdot \sum_{i=1}^{n} d_{i}-\bar{d}^{2} ; \\
d_{i}=\sum_{j=1}^{m} r_{i j} ; \quad \bar{d}=\frac{m \cdot n+1}{2} ;\end{array}$ & $\begin{array}{l}m \text { - кількість експертів; } \\
r_{i j} \text { - оцінка } i \text {-ого параметра, яка } \\
\text { визначена ј-uм експертом; } \\
d \text { - сума оцінок } i \text {-mого параметра, } \\
\text { яка визначена } \mathrm{j}-u м \text { експертом; }\end{array}$ \\
\hline
\end{tabular}


Зазвичай в практиці експертного дослідження в якості середньогрупової оцінки використовується медіана (тобто таке число вибірки, для якого чітко половина 3 елементів вибірки більше нього, а інша половина менше нього[12]). Однак в нашому дослідженні найбільш важливо врахувати рівень компетентності та досвід експертів. Тому кінцева оцінка параметра (тобто ваговий коефіцієнт) для усієї групи експертів приймалася рівною середньозваженому значенню балів, виставлених усіма експертами.

Таблиця 4. Середньогрупові оцінки та вагові коефіцієнти параметрів оцінювання.

Table 4. Average group estimates and weighting factors of evaluation parameters.

\begin{tabular}{|l|l|l|l|}
\hline № параметру* & $\begin{array}{c}\text { Середня арифме- } \\
\text { тична оцінка }\end{array}$ & Медіана & $\begin{array}{c}\text { Середньозважена } \\
\text { оцінка } \\
\text { (ваговий коефіціснт) }\end{array}$ \\
\hline 1.1 & 9,9 & 10 & $\mathbf{9 , 9}$ \\
\hline 1.2 & 7,6 & 8 & $\mathbf{7 , 6}$ \\
\hline 1.3 & 9,8 & 10 & $\mathbf{9 , 7}$ \\
\hline 1.4 & 7,5 & 7,5 & $\mathbf{7 , 6}$ \\
\hline 1.5 & 7,8 & 8 & $\mathbf{7 , 8}$ \\
\hline 1.6 & 8,3 & 8 & $\mathbf{8 , 2}$ \\
\hline 1.7 & 8,5 & 8,5 & $\mathbf{8 , 5}$ \\
\hline 1.8 & 8,3 & 8,5 & $\mathbf{8 , 3}$ \\
\hline 1.9 & 5,5 & 6 & $\mathbf{5 , 5}$ \\
\hline 1.10 & 5,0 & 6 & $\mathbf{5 , 0}$ \\
\hline 1.11 & 7,1 & 7,5 & $\mathbf{7 , 0}$ \\
\hline 1.12 & 7,8 & 8 & $\mathbf{7 , 9}$ \\
\hline 1.13 & 7,8 & 8 & $\mathbf{7 , 9}$ \\
\hline 1.14 & 7,8 & 7,5 & $\mathbf{7 , 9}$ \\
\hline 1.15 & 6,5 & 6,5 & $\mathbf{6 , 6}$ \\
\hline 1.16 & 9,3 & 10 & $\mathbf{9 , 2}$ \\
\hline 1.17 & 7,9 & 8 & $\mathbf{7 , 9}$ \\
\hline 1.18 & 7,5 & 8 & $\mathbf{7 , 4}$ \\
\hline 2.1 & 4,9 & 5 & $\mathbf{4 , 9}$ \\
\hline 2.2 & 3,7 & 4 & $\mathbf{3 , 7}$ \\
\hline 2.3 & 4,9 & 5 & $\mathbf{4 , 9}$ \\
\hline 2.4 & 3,3 & 3,5 & $\mathbf{4 , 3}$ \\
\hline 2.5 & 4,5 & 4,5 & $\mathbf{4 , 4}$ \\
\hline 2.6 & 4,4 & 4,5 & $\mathbf{3 , 8}$ \\
\hline 2.7 & 3,8 & 4 & $\mathbf{3 , 2}$ \\
\hline 2.8 & 3,2 & 3 & $\mathbf{4 , 0}$ \\
\hline 2.9 & 3,9 & 4 & $\mathbf{3 , 4}$ \\
\hline 2.10 & 4,0 & 4 & $\mathbf{4 , 5}$ \\
\hline 2.11 & 3,3 & 5 & \\
\hline 2.12 & 4,4 & & \\
\hline
\end{tabular}

* - назви параметрів відповідають табл. 1 і табл. 2.

Для врахування узгодженості думок експертів по кожному параметру розраховувався коефіцієнт варіації, який дозволяє оцінити відносний розкид даних у вибірці i, тим самим, встановити ступень однорідності параметрів об'єкта досліджень. У статистиці прийнято: якщо значення коефіцієнта варіації менше $33 \%$, то сукупність (вибірка) вважається однорідною, в іншому випадку - неоднорідною [12].

Як видно з рис. 4. і рис. 5, коефіцієнт варіації експертних оцінок змінюється від 0,06 до 0,38. Тільки три параметри мають коефіцієнт варіації вище $33 \%$, що вказує на достатню узгодженість думок експертів.

Для того, щоб виявити узгодженість думок експертів в цілому за усіма параметрами, використовувався коефіцієнт конкордації Кендалла. Формула для розрахунків коефіцієнта наведена у табл. 3. Як що величина коефіцієнта конкордації (W) перевищує значення 0,6 , то ступень узгодженості оцінок експертів велика. Коефіцієнт конкордації Кендалла проведеної експертної оцінки дорівнює 0,55 , що вказує на наявність середнього ступеня узгодженості думок експертів. Тому другий тур опитування не був потрібен. 


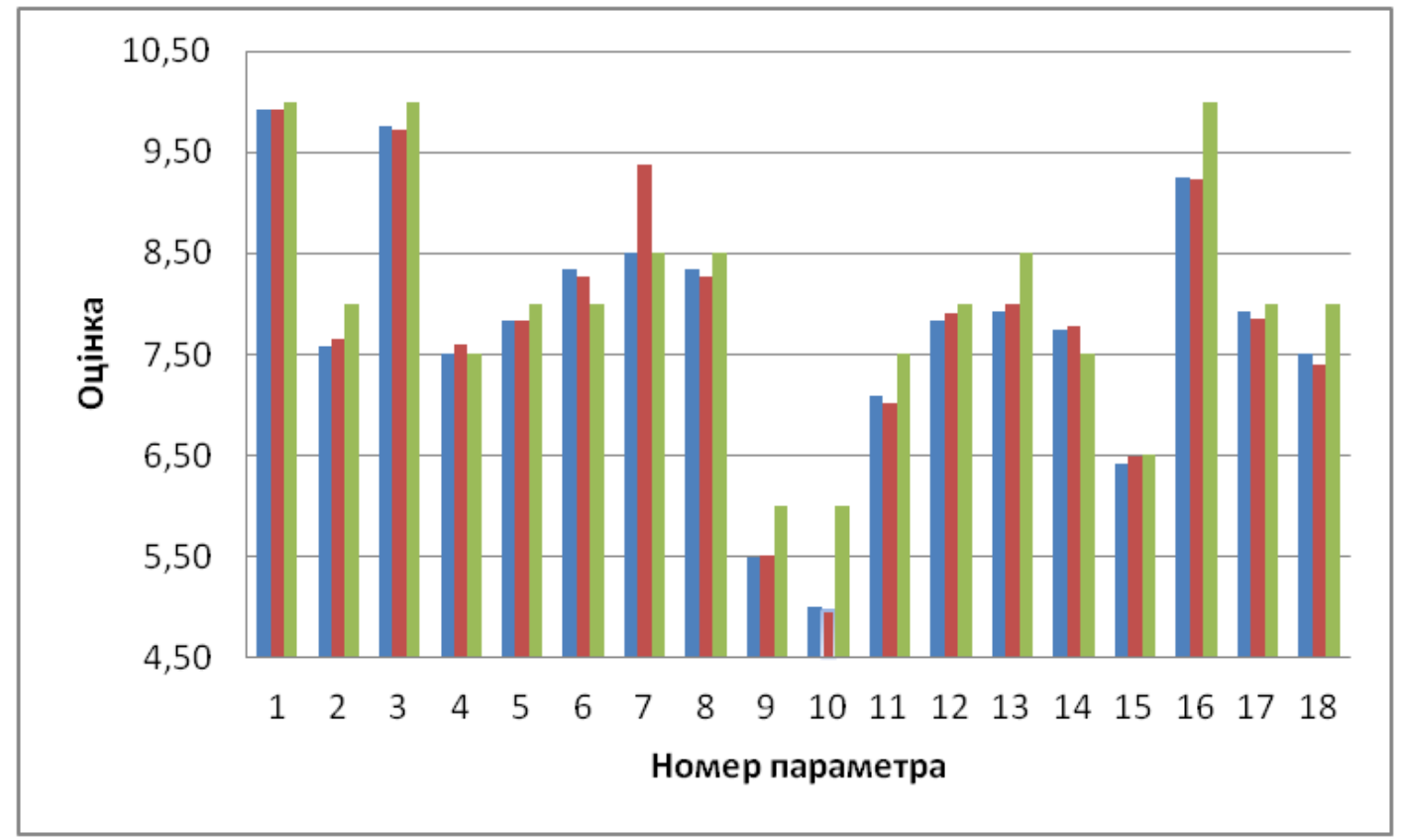

Рис. 2. Порівняння статистичних характеристик оцінок експертів (перша категорія параметрів). $\square$ - середня; $\square$ - середньозважена; $\square$ - медіана.

Fig. 2. Comparison of statistical characteristics of expert assessments (the first category of parameters). $\square$ - average; $\square$ - weighted average; $\square$ - median.

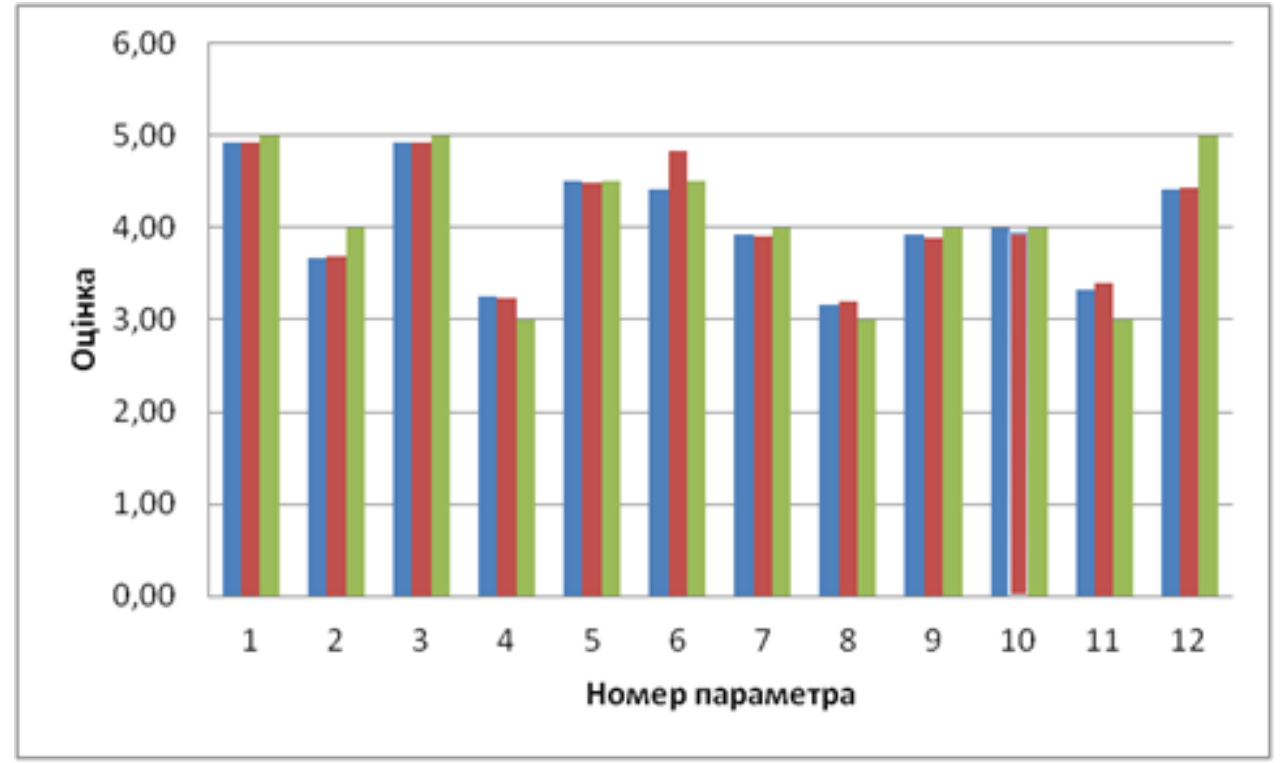

Рис. 3. Порівняння статистичних характеристик оцінок експертів (друга категорія параметрів). $\square$ - середня; $\square$ - середньозважена; $\square$ - медіана.

Fig. 3. Comparison of statistical characteristics of expert assessments (second category of parameters). $\square$ - average; $\square$ - weighted average; $\square$ - median. 


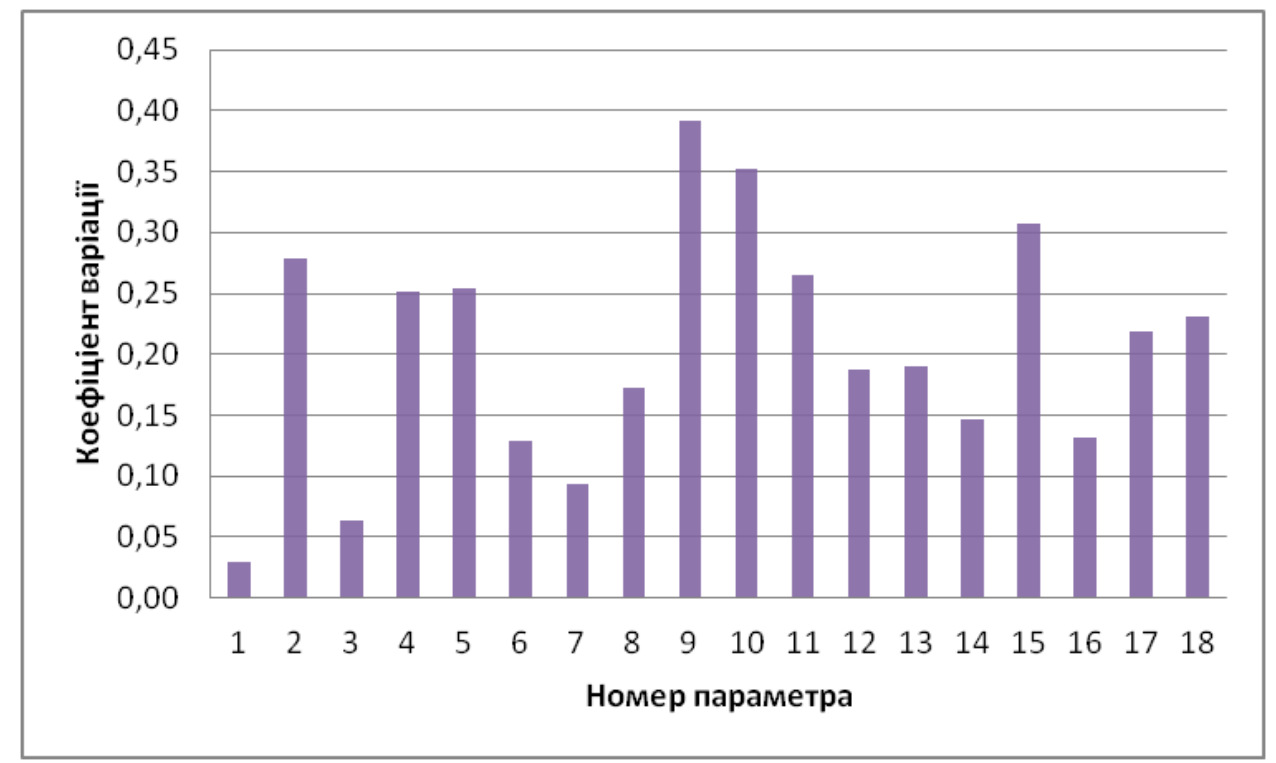

Рис. 4. Коефіціснт варіації експертних оцінок параметрів першої категорії.

Fig. 4. Coefficient of variation of expert assessments of the parameters of the first category.

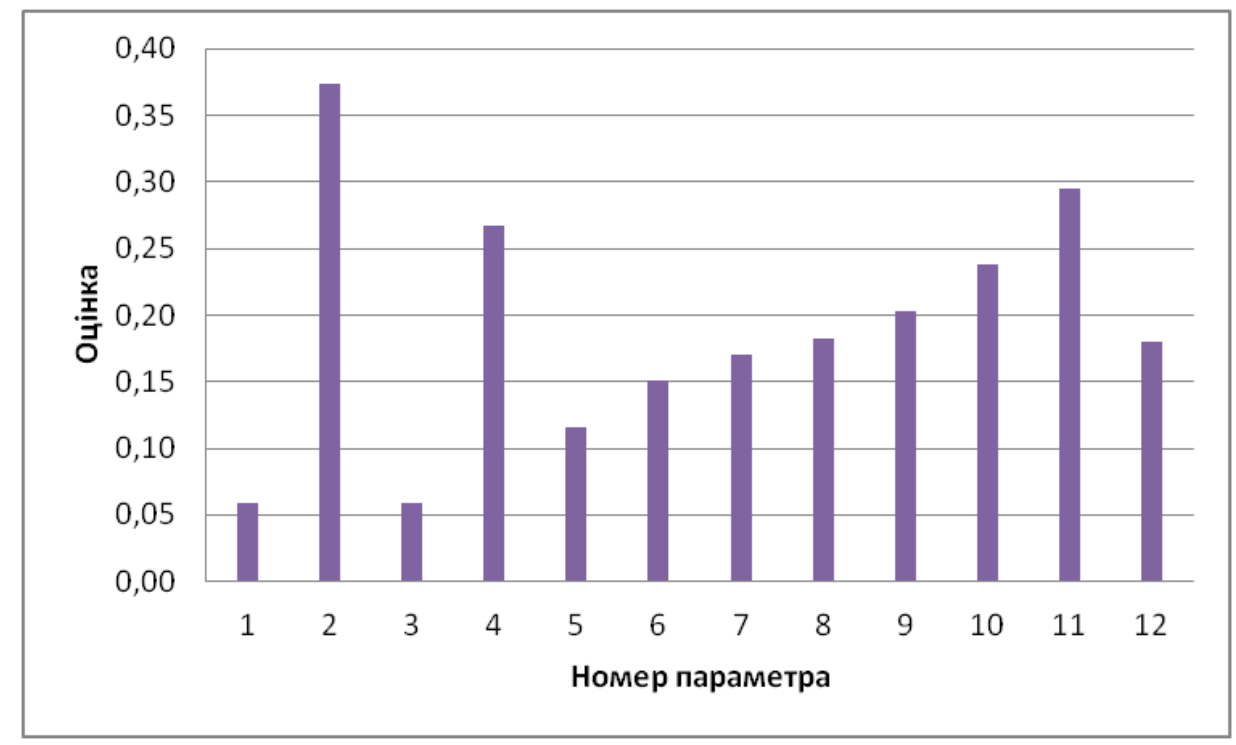

Рис. 5. Коефіціснт варіації експертних оцінок параметрів другої категорії.

Fig. 5. Coefficient of variation of expert assessments of the parameters of the second category.

Висновки. Незважаючи на наявність в Україні величезного масиву геотермічних даних, на теперішній час не існує методики, яка б уніфікувала процес первинної обробки та відбору геотермальних об'єктів, перспективних для практичного освоєння цього ресурсу. В результаті проведених досліджень було визначено перелік параметрів, які впливають на перспективність геотермального об'єкта, і оцінені вагові коефіцієнти цих параметрів. Проведене експертне оцінювання $є$ першим етапом створення методики відбору геотермальних об'єктів за первинними даними. Надалі передбачається для кожного параметра, який впливає на перспективність геотермального об'єкта, створити в кількісних показниках шкалу рівнів з відповідними балами. Оцінювання перспективності об'єктів пропонується виконувати методом зважених сум, тобто при визначенні перспективності об'єкта в цілому бали по кожному з параметрів підсумовується. При цьому важливість параметра враховується шляхом використання вагових коефіцієнтів, які були одержані в даному дослідженні. Перелік параметрів, визначений експертним оцінюванням, може бути рекомендований для використання під час створення електронних баз даних.

1. Морозов Ю.П., Барило А.А. Шляхи визначення енергетичного потенціалу геотермальних джерел енергії. Актуальні проблеми та перспективи розвитку геології: наука 
й виробництво. Матеріали Міжнародного геологічного форуму. К. УкрДГРІ. 2017. С. 250-253.

2. Morozov Y.P., Barylo A.A. Geothermal Energy Use, Country Update for Ukraine. European Geothermal Congress 2019 Den Haag. The Netherlands. 2019. 11-14 June. C. 1-6.

3. Іванюта М.М. Атлас нафтових і газових родовищ України (в 6 т.). Львів. Вид-во «Центр Свропи». 1998. Т.1-3. 1421 c. T.4-5. 707 c. T.6. $224 \mathrm{c}$

4. Горбатенко В., Пертенко I. Метод «Делфі» та специфіка його застосування у прогнозних розробках. Політичний менеджмент. 2008. № 6. С. 174-182.

5. Рупосов В.Л. Методы определения количества экспертов. Вестник ИрГТУ. 2015. № 3(98). С. 286-292.

6. Алхасов А.Б. Геотермальная энергетика: проблемы, ресурсы, технологии. М. Физматлит. 2008. С. 367.

7. Богуславский Э.И., Богуславская Л.И. Влияние геотермальных параметров коллекторов на экономику их разработки. Успехи современного естествознания. 2004. №4. C. $160-161$.

8. Барило А.А., Морозов Ю.П. Оцінка енергетичного потенціалу окремих геотермальних родовищ України.

Відновлювана енергетика. 2017. № 1. С. 72-79.

9. Закиров С.Н. Теория и проектирование разработки газовых и газоконденсатных месторождений. М. Недра. 1989. 333 c.

10. Морозов Ю.П. Добыча геотермальных ресурсов и аккумулирование теплоты в подземных горизонтах. К. Наукова думка. 2017. 197 с.

11. Джаватов Д.К., Азизов А.А. Оценка эффективности бинарной электростанции на основе геотермальных циркуляционных систем с вертикальными и горизонтальными скважинами. Энергосбережение и водоподготовка. М. ЭНИВ. 2019. № 6(122). С. 68-73.

12. Мазуренко В.П. Теорія статистики: Навчальний посібник. К. Видавниче - поліграфічний центр “Київський університет ". 2006. 232 с.

\section{REFERENCES}

1. Morozov Y.P., Barylo A.A. Shlyakhy vyznachennya enerhetychnoho potentsialu heotermal'nykh dzherel enerhiyi. Aktualni problemy ta perspektyvy ro-zvytku heolohiyi: nauka y vyrobnytstvo. [Ways to determine the energy potential of geothermal energy sources. Actual problems and prospects of development of geology: science and production]. International Geological Odesa Forum. Kiev. UkrDGRI. 2017. Pp. 250-253. [in Ukrainian].

2. Morozov Y.P., Barylo A.A. Geothermal Energy Use, Country Update for Ukraine. European Geothermal Congress 2019 Den Haag. The Netherlands. 2019. 11-14 June. C. 1-6. [in English].

3. Ivaniuta M.M. Atlas naftovykh i hazovykh rodovyshch Ukrainy ( $v 6$ t.). [Atlas of Oil and Gas Deposits of Ukraine (6 v.)]. Tsentr Yevropy. Lviv. 1998. Vol. 1-3. $1421 \mathrm{p}$ Vol. 4-5. 707 p. Vol. 6. 224 p. [in Ukrainian].

4. Gorbatenko V., Petrenko I. Metod «Delfi») ta spetsyfika yoho zastosuvannya u prohnoznykh rozrobkakh. [Delphi Method and the specifics of its use in predictive engineering]. Political management. 2008. No. 6. Pp. 174-182. [in Ukrainian].

5. Rupusov V.L. Metody opredeleniya kolichestva ekspertov. [Methods to determine a number of experts]. Bulletin of Irkutsk State Technical University. 2015. No. 3. Pp. 286-292. ISSN 1814-3520. [in Russian].

6. Alkhasiv A.B. Geotermalnaya energetika: problemy, resursy, tekhnologii. [Geothermal energy: problems, resources, technologies]. Moscow. Russia. Fizmatlit. 2008. 367 p. [in Russian].

7. Boguslavskiy E.I., Boguslavskaya L.I. Vliyaniye geotermalnykh parametrov kollektorov na ekonomiku ikh raz- rabotki. [The influence of geothermal collector parameters on the economics of their development]. Uspehi sovremennogo estestvoznaniya. Moscow. Russia. 2004. No. 4. Pp. 160-161. [in Russian].

8. Morozov Y.P., Barylo A.A. Otsinka enerhetychnoho potentsialu okremykh heotermalnykh rodovyshch Ukrayiny. [Estimation of energy potential of individual geothermal deposits in Ukraine]. Ukraine. Kiev. Vidnovluvana energetika. 2017. No. 1. Pp. 72-79. [in Ukrainian].

9. Zakirov S.N. Teoriya i proyektirovaniye razrabotki gazovykh i gazokondensatnykh mestorozhdeniy. [Theory and design of development of gas and gas condensate fields]. Russia. Moscow. Nedra. 1989. Pp. 330-333. [in Russian].

10. Morozov Y.P. Dobycha geotermalnykh resursov i akkumulirovaniye teploty v podzemnykh gorizontakh. [Extraction of geothermal resources and heat storage in underground horizons]. K. Naukova dumka. 2017. 197 p. [in Russian].

11. Dzhavatov D.K., Azizov A.A. Otsenka effektivnosti binarnoy elektrostantsii na osnove geotermalnykh tsirkulyatsionnykh sistem s vertikalnymi i gorizontalnymi skvazhinami. [Evaluation of the efficiency of a binary geothermal power plant based on geothermal circulation systems with vertical and horizontal wells]. Russia. Moscow. Energosnabzhenie i vodopodgotovka. 2019. No. 6(122). Pp. 68-73. [in Russian].

12. Mazurenko V.P. Teoriya statystyky. [Statistics Theory]. Textbook. Ukraine. Kiev. Vidavniche-polIgrafIchniy tsentr "Kiyivskiy universitet". 2006. 232 p. [in Ukrainian].

\section{АНАЛИЗ ПРИОРИТЕТНОСТИ ПАРАМЕТРОВ ДЛЯ ОЦЕНКИ ПЕРСПЕКТИВНОСТИ ИСПОЛЬЗОВАНИЯ ГЕОТЕРМАЛЬНЫХ ОБЬЕКТОВ}

\section{А.А. Барило}

Институт возобновляемой энергетики НАН Украины, 02094, ул. Гната Хоткевича 20А, г. Киев, Украина.

В статье методом экспертной оценки выполнен анализ приоритетности параметров геотермальных объектов для определения возможности и перспективности их использования в иелях энергоснабжения. Под геотермальным объектом понимается условная скважина, на базе которой возможно создание системы геотермального энергоснабжения с учетом наличия потенциального потребителя. Для экспертной оченки была разработана опросная анкета $u$ выбранная репрезентативная группа в количестве 12 человек. Средний коэффичиент компетентности экспертов составил 8 баллов по десятибалльной шкале. Рассмотрень параметры двух категорий: первые связаны с наличием геотермального ресурса, вторые - с условиями транспортировки и особенностями потенциальных потребителей энергии. Всего в опросе анализировалось 30 параметров. Для каждого параметра устанавливались весовые коэффиииентыл. Результаты опроса были обработаны путем нахождения средней арифметической, средне взвешенной и медианы оценок. Степень согласованности мнений экспертов по каждому параметру определялся методом нахождения коэффициента вариации, а для всего экспертного опроса в иелом - коэффициента конкордации Кенделл. Расчеты показали, что согласованность оченок экспертов достаточна для принятия решения об определении перечня приоритетных параметров и их весовых коэффициентов. Полученные результаты могут быть использованы при создании электронных баз данных геотермальных и при разработке методики выбора перспективных скважин для первоочередного освоения геотермальных ресурсов. Библ. 10, табл. 4, puc. 5.

Ключевые слова: экспертная оценка, геотермальный объект, параметр, весовой коэффициент, статистическая характеристика, согласованность.

Стаття надійшла до редакції 15.05.20 Остаточна версія 08.06.20 